\title{
Endophytic and canker-associated Botryosphaeriaceae occurring on non-native Eucalyptus and native Myrtaceae trees in Uruguay
}

\author{
C. A. Pérez ${ }^{1,2}$, M. J. Wingfield ${ }^{3}$, B. Slippers ${ }^{3}$, N. A. Altier ${ }^{4}$ and R. A. Blanchette ${ }^{1}$
}

(1) Department of Plant Pathology, University of Minnesota, 495 Borlaug Hall, 1991 Upper Buford Circle, St. Paul, MN 55108, USA

(2) Departamento de Protección Vegetal, EEMAC, Facultad de Agronomía, Universidad de la República, Ruta 3, km 363, Paysandú, Uruguay

(3) Forestry and Agricultural Biotechnology Institute (FABI), University of Pretoria, Pretoria, South Africa

(4) Instituto Nacional de Investigación Agropecuaria (INIA), Ruta 48, km 10, Canelones, Uruguay

\section{A. Pérez}

Email: caperez@fagro.edu.uy

\begin{abstract}
Species of the Botryosphaeriaceae are important pathogens causing cankers and die-back on many woody plants. In Uruguay, Neofusicoccum eucalyptorum, $N$. ribis and B. dothidea have previously been associated with stem cankers on plantation-grown Eucalyptus globulus. However, very little is known regarding the occurrence and species diversity of Botryosphaeriaceae in native Myrtaceae forests or what their relationship is to those species infecting Eucalyptus in plantations. The objectives of this study were to identify the Botryosphaeriaceae species present as endophytes or associated with cankers in both introduced and native tree hosts in Uruguay, and to test the pathogenicity of selected isolates obtained from native trees on Eucalyptus. Symptomatic and asymptomatic material was collected countrywide from Eucalyptus plantations and native Myrtaceae trees. Single spore cultures were identified based on conidial morphology and comparisons of DNA sequences of the ITS and EF1- $\alpha$ regions. Six Botryosphaeriaceae species were identified. Botryosphaeria dothidea, N. eucalyptorum and specimens residing in the N. parvum-N. ribis complex were isolated from both introduced Eucalyptus and native Myrtaceae trees, whereas Lasiodiplodia pseudotheobromae was found only on Myrcianthes pungens. Diplodia pseudoseriata sp. nov. and Spencermartinsia uruguayensis sp. nov. are novel species found only on native myrtaceous hosts. Pathogenicity tests showed that isolates obtained from native trees and identified as L. pseudotheobromae, $N$. eucalyptorum and the N. parvum-N.ribis complex are pathogenic to $E$. grandis. Interestingly, Lasiodiplodia pseudotheobromae has not previously been found on Eucalyptus in Uruguay and represents a potential threat to this host.
\end{abstract}

\section{Introduction}

The Botryosphaeriaceae is a very diverse group of fungi that includes endophytes and plant pathogens of trees and plants (Alves et al. 2008; Huang et al. 2008; Lazzizera et al. 2008). It is well known that certain endophytic fungi may become pathogenic when trees and plants become stressed (Old et al. 1990; Pusey 1989; Wene and Schoeneweiss 1980). In this regard, diseases caused by Botryosphaeriaceae are almost exclusively associated with some type of stress and drought stress is one of the most commonly cited factors associated with these fungi (Slippers and Wingfield 2007). 
Botryosphaeriaceae have been reported to cause serious diseases on Eucalyptus worldwide (Zhou et al. 2008). Stem cankers and die-back of Eucalyptus spp. have commonly been associated with Botryosphaeria dothidea (Barnard et al. 1987; Old and Davison 2000; Smith et al. 1994; Yuan and Mohammed 1999), but in recent years a number of other species of the Botryosphaeriaceae have also been associated with diseases on this host (Slippers et al. 2004a; Slippers et al. 2007). Severe Botryosphaeria cankers have also been observed on Eucalyptus in Uruguay causing growth loss, tree mortality, and coppice failure (Balmelli and Resquin 2005). Additionally, due to the explosive increase in the area planted to introduced species, the biotic interactions between introduced Eucalyptus and native Myrtaceae trees has provided an intriguing situation to study.

Uruguay has a rich diversity of native Myrtaceae trees with a total of 35 species reported by Brussa and Grela (2007). It is of general concern that biotic exchange of pathogens may occur between introduced Eucalyptus and native trees, which could result in negative economic impact as well as an ecological disturbance. Endophytic B. dothidea, Neofusicoccum eucalyptorum (= Botryosphaeria eucalyptorum) and N. ribis (=B. ribis) were found in some Eucalyptus spp. (Alonso 2004; Bettucci and Alonso 1997), while Myrceugenia glaucescens is the only native Myrtaceae host on which a species of Botryosphaeriaceae, B. dothidea, has been found (Bettucci et al. 2004).

Eucalyptus spp. are non-native in Uruguay and pathogens affecting these trees could have been introduced. However, native trees could also serve as an important source of fungi pathogenic to Eucalyptus, as is being found in other parts of the world (Rodas et al. 2008; Wingfield 2003). Burgess et al. (2006) have demonstrated that there is no restriction to the movement of $N$. australe between native forests and plantations in Australia and it has been demonstrated repeatedly that Myrtaceae are hosts of many pathogens that can infect Eucalyptus spp. (Coutinho et al. 1998; Pavlic et al. 2007; Seixas et al. 2004; Wingfield et al. 2001; Wingfield 2003). Very little is known about the Botryosphaeriaceae species occurring on introduced and native Myrtaceae hosts in Uruguay. The aim of this study was, therefore, to gain a more comprehensive understanding of the species that are endophytes and those that are associated with cankers, and to test the pathogenicity of the isolates obtained from native trees on Eucalyptus.

\section{Materials and Methods}

\section{Sampling and fungal isolates}

Between 2005 and 2008 several surveys were conducted throughout Uruguay with the aim of isolating and identifying fungi present on native Myrtaceae and non-native Eucalyptus species. Symptomatic and asymptomatic material was collected from Eucalyptus plantations and nearby native forest trees (less than $500 \mathrm{~m}$ away). Endophytic microorganisms were isolated from asymptomatic material. Leaf, petiole and twig sections were sequentially surface-disinfested in $70 \%$ ethyl alcohol for $1 \mathrm{~min}$, immersed in $0.4 \%$ sodium hypochlorite for $2 \mathrm{~min}$, then rinsed twice in sterile distilled water and blotted dry on sterile filter paper. Disinfested plant tissue was placed on $2 \%$ malt extract agar (MEA) (2\% malt extract, 1.5\% agar; Oxoid, Basingstoke, England). Plates were incubated at room temperature $\left(\sim 20^{\circ} \mathrm{C}\right)$ for 1 week. Colonies resembling Botryosphaeriaceae were selected for this study, and maintained on $2 \%$ MEA at $8^{\circ} \mathrm{C}$. To verify the efficacy of the surface disinfestation and to assure the growth of only endophytic microorganisms, imprints of sample surfaces were made on MEA plates and observed for 1 week to confirm that fungi did not grow (Hyde and Soytong 2008).

Isolations from cankers were done from wood tissue at the advancing zone of the lesion, which was surface-disinfested in 70\% ethyl alcohol for $30 \mathrm{~s}$, rinsed twice in sterile distilled water and blotted dry on sterile filter paper. Disinfested tissue was placed on 2\% MEA and incubated at room 
temperature $\left(\sim 20^{\circ} \mathrm{C}\right)$ for 1 week. Colonies resembling Botryosphaeriaceae were subcultured to a fresh $2 \%$ MEA plate for further investigation.

\section{Morphological characterization}

Isolates were stimulated to produce fruiting structures (pycnidia) and conidia, by growing them on $1.5 \%$ water agar (WA) (Sigma Chemicals, St. Louis, MO) with sterilized pine needles placed onto the medium surface. Plates were incubated at $22^{\circ} \mathrm{C}$ under black light until pycnidia were observed on the pine needles (approx. 3 weeks after plating). Monoconidial cultures were obtained by plating a conidial suspension from two pycnidia, suspended in $300 \mu \mathrm{l}$ of sterile water, and plated onto WA. Germinating conidia were lifted from the agar plates and transferred to fresh $2 \%$ MEA.

For morphological characterization, pycnidia and conidia produced on pine needles were mounted on microscope slides, and examined under a standard light microscope Motic DMBA200-B (Motic $\AA$, British Columbia, Canada). Isolates were grouped by conidial morphology and host, and at least two specimens per group were further analyzed using molecular techniques.

\section{DNA extraction, PCR, sequencing and phylogenetic analysis}

DNA extraction from the 49 isolates listed in Table 1 was done as described in Pérez et al. (2009).The phylogenetic analyses were performed in two steps. First, the internal transcribed spacer region of the ribosomal DNA operon (ITS) was amplified for all isolates and compared with Botryosphaeriaceae species found on Eucalyptus spp. worldwide. The second step was to confirm the identification of the Diplodia sp. clade and the Spencermartinsia sp. isolate with the analysis of the rDNA ITS region along with part of the EF1- $\alpha$ region. Analyzes of both DNA regions were performed separately and combined, to test congruence.

Table 1. List of isolates used in this study. 


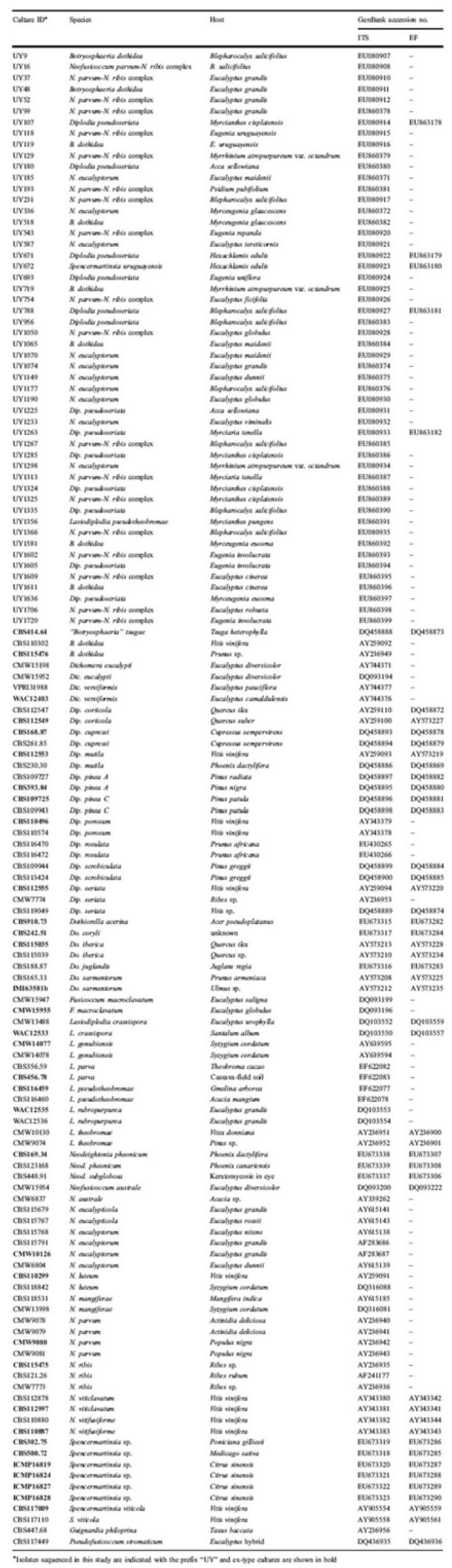


The ITS region was amplified for all isolates using primers ITS1 and ITS4 (White et al., 1990). Polymerase Chain Reaction (PCR) amplifications were performed as described in Pérez et al. (2009). PCR products were then stained with SYBR Green nucleic acid dye (MBL International, Woburn, MA) and visualized on 1.5\% agarose gel under UV light. Amplicons were then purified and prepared for sequencing using ExoSAP-IT PCR clean-up kit (USB Corp., Cleveland, OH) following manufacturer's instructions. The same primers were used for sequencing reactions performed with the ABI Prism Dye Terminator Cycle Sequencing Ready Reaction Kit (Applied Biosystems, Foster City, CA) and an ABI Prism 377 automated DNA sequencer. Sequences were obtained in both directions and assembled using ChromasPro software version 1.33 (Technelysium Pty. Ltd., Eden Prairie, MN). ITS sequences were subjected to BLAST searches in NCBI GenBank (http://www.ncbi.nlm.nih.gov/blast/Blast.cgi), and sequences of the closest matching species were downloaded. Sequences of ex-type cultures were preferred when available, along with sequences of all the Botryosphaeriaceae species previously reported on Myrtaceous hosts. Multiple sequence alignments were made online using the E-INS-i strategy in MAFFT version 6 (http://align.bmr.kyushu-u.ac.jp/mafft/online/server/) (Katoh et al. 2005).

Phylogenetic analysis was performed using PAUP Version 4.0b10 (Swofford 2002) for maximum parsimony analysis, and Mr. Bayes v3.1.2 (Ronquist and Huelsenbeck 2003) for Bayesian analysis. Maximum parsimony analysis was performed using the heuristic search option with simple taxa additions and tree bisection and reconnection (TBR) as the branch-swapping algorithm. Gaps were treated as missing data and all characters were treated as unordered and of equal weight. Support for the nodes of the shortest trees was determined by analysis of 1,000 bootstrap replicates (Hillis and Bull 1993). Tree length (TL), consistency index (CI), retention index (RI), and homoplasy index (HI) were calculated.

The best nucleotide substitution model for the Bayesian analysis was selected using MrModeltest v2.2 (Nylander 2004) from which the SYM $+\mathrm{I}+\mathrm{G}$ model was selected using Akaike Information Criterion (AIC). Four MCMC chains starting from a random tree topology were run over 10 million generations. Trees were sampled every 100th generation and burn-in value was set at 200 since the likelihood values were stationary after 20,000 generations. To obtain the estimates for the posterior probabilities, a 50\% majority rule consensus of the remaining 99,801 trees was computed from a total of 199,602 sampled trees.

The EF1- $\alpha$ region was amplified to confirm the identity of the Diplodia sp. clade and the Spencermartinsia $\mathrm{sp}$. isolate. The EF1- $\alpha$ was amplified using primers EF-AF (5' CATCGAGAAGTTCGAGAAGG 3') and EF-BR (5' CRATGGTGATACCRCGCTC 3') (Sakalidis 2004). PCRs were performed in a $25-\mu 1$ reaction mixture of $0.5 \mu 1$ of Taq DNA polymerase (Roche Molecular Biochemicals, Almeda, CA), $1 \mathrm{X}$ buffer and $\mathrm{MgCl}_{2}$ mixture (10 mM Tris- $\mathrm{HCl}, 1.5 \mathrm{mM}$ $\mathrm{MgCl} 2,50 \mathrm{mM} \mathrm{KCl}), 0.2 \mathrm{mM}$ of each dNTP, $0.15 \mathrm{mM}$ of each primer and made up to a final volume of $25-\mu 1$ with water. PCR amplifications were performed in a MJ Research PTC 200 DNA Engine Thermal Cycler PCR (MJ Research, Reno, NV) with the following parameters: $94^{\circ} \mathrm{C}$ for 2 min initial denaturation; 40 cycles of $94^{\circ} \mathrm{C}$ for $30 \mathrm{~s}, 55^{\circ} \mathrm{C}$ for $30 \mathrm{~s}, 72^{\circ} \mathrm{C}$ for $1 \mathrm{~min}$; and $72^{\circ} \mathrm{C}$ for 7 min final extension; hold at $10^{\circ} \mathrm{C}$. Sequences were obtained in both directions and assembled using ChromasPro and aligned with sequences of the closest related species obtained from GenBank; sequences of ex-type cultures were utilized when available. Multiple sequence alignments were also made online using the E-INS-i strategy in MAFFT version 6.

ITS and EF1- $\alpha$ sequence datasets were examined for congruence by using the Partition Homogeneity Test in PAUP (Farris et al. 1995; Huelsenbeck et al. 1996). Thus isolates UY107, UY671, UY788 and UY1263 from the Diplodia sp. clade plus isolate UY672 were subjected to ITS, EF1- $\alpha$ and combined analyses using neighbor-joining and maximum parsimony. The original alignment was populated with corresponding sequence data of all the species residing in Diplodia, 
Neodeightonia, Dothiorella, Spencermartinsia, and representative species of Neofusicoccum and Lasiodiplodia available in GenBank. Phylogenetic analysis was performed using PAUP Version 4.0b10. Best models for neighbor-joining analysis was determined from the AIC Modeltest version 3.7 (Posada and Crandall 1998) as K81uf $+\mathrm{I}+\mathrm{G}$, $\mathrm{TrN}+\mathrm{I}+\mathrm{G}$ and $\mathrm{TrN}+\mathrm{I}+\mathrm{G}$ for the ITS, EF1- $\alpha$ and combined dataset, respectively. Gaps generated in the alignment process during the comparison were treated as missing data and all characters were treated as unordered and of equal weight. Ties were broken randomly when found. All the sequences obtained in this study were deposited in GenBank (Table 1). In addition, corresponding alignments were deposited in TreeBASE (SN3975, for alignments presented in Figs. 1 and 2). 


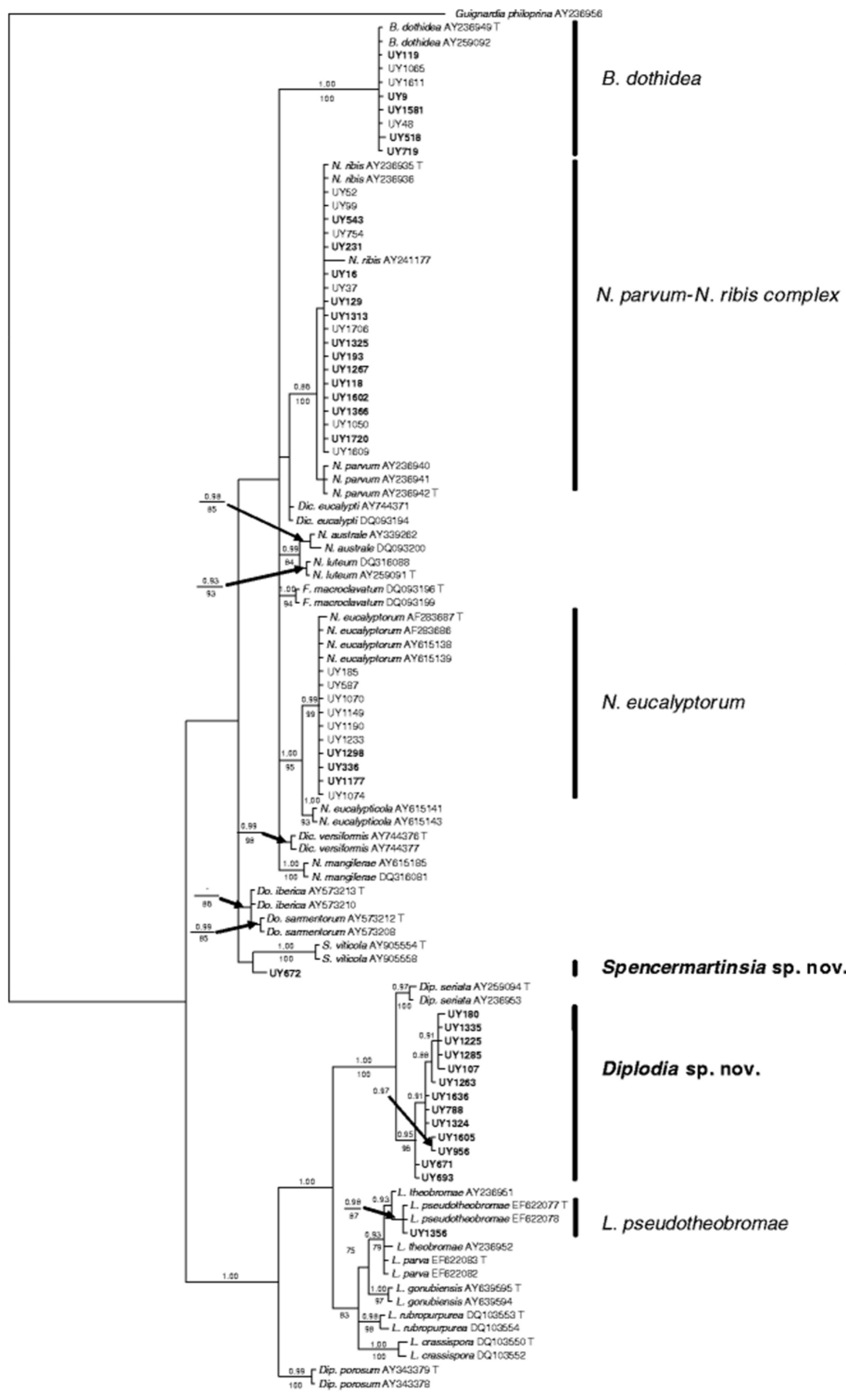


Fig. 1. A Bayesian tree based on ITS sequences showing the phylogenetic relationship among the isolates obtained in the present study and Botryosphaeriaceae species obtained from GenBank (Table 1). Posterior probabilities (10 million generations) of the Bayesian analysis and bootstrap values (1,000 replicates) of the maximum parsimony analysis are shown above and below branches, respectively. Guignardia philoprina was the outgroup taxon. Sequences obtained in this study are indicated with a prefix "UY", and those obtained from native Myrtaceae hosts are in bold. Ex-type cultures are labeled with a " $T$ " at the end. The scale bar indicates 0.5 substitutions per site. 


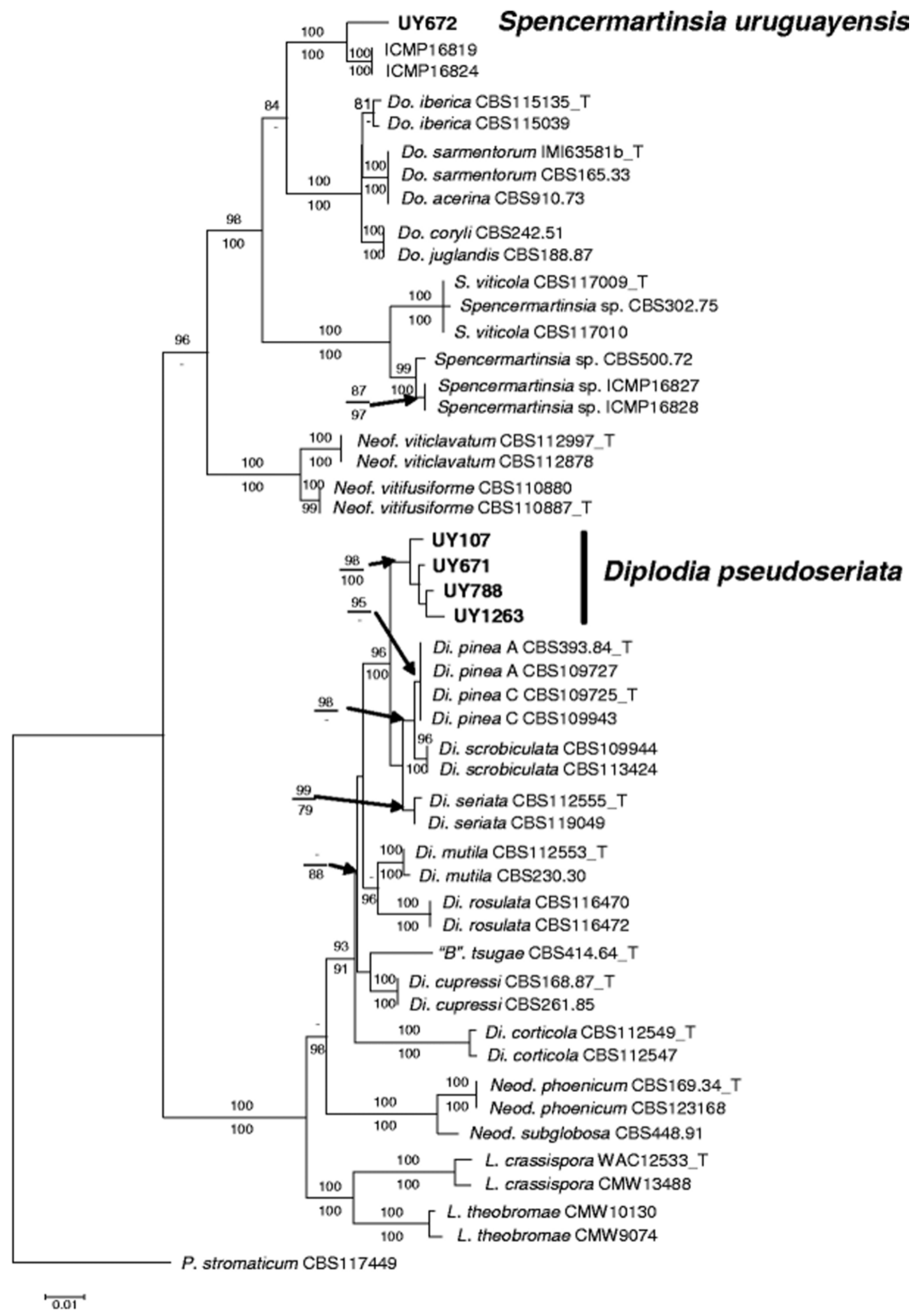


Fig. 2. Distance tree obtained from neighbor-joining analysis of the combined ITS and EF1- $\alpha$ dataset using model $\operatorname{TrN}+\mathrm{I}+\mathrm{G}$ indicating the location of the "UY" unknowns. Species name and culture ID is shown for each sequence. Sequences labeled with a " $T$ " at the end correspond to the ex-type culture. Bootstrap values of 1,000 replicates of neighbor-joining and maximum parsimony analyses are shown above and below branches, respectively. Only bootstrap values higher than $75 \%$ are shown. Pseudofusicoccum stromaticum was used as the outgroup taxon. Branch lengths are scaled and scale bar is 0.01 nucleotide substitutions per site.

\section{Pathogenicity tests}

Selected isolates representing the six species of Botryosphaeriaceae obtained from native trees were tested for pathogenicity on Eucalyptus. Results obtained with N. eucalyptorum inoculations have been presented previously (Pérez et al. 2009). Inoculations were performed on 4 month-old $E$. grandis seedlings using an adaptation of the method described by Simeto et al. (2007). Briefly, the region of the stem to be wounded was surface disinfested with $70 \%$ ethyl alcohol. A wound was made on the stem of each seedling at approximately $10 \mathrm{~cm}$ above the soil level and between two nodes using a cork borer of $5 \mathrm{~mm}$ diameter to remove the bark and expose the cambium. Five millimeter mycelial plugs from 1 week old pure cultures, on $2 \%$ MEA, were placed into the wound with the mycelial surface facing the cambium. A piece of sterile cotton, soaked in sterile water, was attached to the inoculated wound with Ready Por $\mathrm{N}^{\circ} 545$ tape (Sagrin S.A., Montevideo, Uruguay) to prevent desiccation of the plug. Each isolate was inoculated into the stems of ten seedlings. Plugs of sterile MEA were inoculated into stems of 10 trees as controls. Inoculated trees were maintained outside under a structure with a plastic roof and open sides with temperatures ranging from 15 to $25^{\circ} \mathrm{C}$. Stem diameter at the site of the inoculation and lesion length were determined and photographed for records a week after inoculation.

To complete Koch's postulates, three inoculated stems per isolate were randomly selected for reisolation of the inoculated fungus. Thus, pieces of wood from the edges of the lesions were surfacedisinfested in $70 \%$ ethyl alcohol for $1 \mathrm{~min}$, immersed in $0.4 \%$ sodium hypochlorite for $2 \mathrm{~min}$, then rinsed twice in sterile distilled water and blotted dry on sterile filter paper. Disinfested plant tissue was placed on $2 \%$ MEA and incubated at room temperature $\left(\sim 20^{\circ} \mathrm{C}\right)$ for 1 week. Fungal identification was based on colony and conidial morphology.

Data were subjected to analysis of variance (ANOVA) using the Generalized Linear Model procedure (PROC GLM) of SAS (release 9.1; SAS Institute, Inc., Cary, NC). The assumptions used in the ANOVA were tested using PROC UNIVARIATE. When the $\mathrm{F}$ test was significant $(\mathrm{P}<0.05)$ the treatment means were compared using Fisher's least significant differences (LSD) at $\mathrm{P}=0.05$. Isolates were grouped by species and comparisons between groups were performed using orthogonal contrasts described by Gomez and Gomez (1984).

\section{Results}

\section{Sampling and fungal isolates}

A total of nine Eucalyptus species and 14 native Myrtaceae species were surveyed countrywide (Table 1). One hundred and thirty four isolates resembling Botryosphaeriaceae were obtained from both groups of hosts. Isolates UY37 and UY185 were isolated from dead tissue from E. grandis and E. maidenii pruning residue, respectively. Specimens UY336, UY1050, UY1065, UY1263, UY1356 and UY1366 were isolated from expanding lesions associated with stem cankers on Myrceugenia glaucescens, E. globulus, E. maidenii, Myrciaria tenella, Myrcianthes pungens, and Blepharocalyx salicifolius, respectively. The remaining isolates were obtained from asymptomatic plant material. All isolates produced conidiomata after 3 weeks of incubation on water agar with 
pine needles under continuous black light.

\section{Morphology and DNA sequence comparisons}

The 134 isolates were placed in six groups based on colony and conidial morphology. A total of 52 isolates representing the six groups were further investigated using DNA sequence comparisons, including 17 obtained from Eucalyptus and 35 from native myrtaceous hosts (Table 1). Phylogenetic analysis of DNA sequence data confirmed that the 52 analyzed isolates reside in the Botryosphaeriaceae. ITS sequences from all isolates were then aligned with Botryosphaeriaceae species previously reported for Myrtaceae, including Eucalyptus. The alignment contained 100 ingroup taxa and Guignardia philoprina as the outgroup taxon. Out of 556 total characters, 292 were constant, 115 variable characters were parsimony-uninformative and 149 were parsimony informative. Heuristic search analysis of the data resulted in one tree (TL $=543$ steps; $\mathrm{CI}=0.715$; RI $=0.949 ; \mathrm{HI}=0.285)$. The maximum parsimony and Bayesian analyses resulted in trees of similar topology (Fig. 1).

Based on the ITS sequences, six different Botryosphaeriaceae species were represented among the 52 isolates analyzed, in agreement with the grouping obtained based on morphological characteristics. Eight of the isolates clustered with $B$. dothidea, ten isolates clustered with $N$. eucalyptorum, 19 isolates clustered within the N. parvum-N. ribis complex. One isolate (UY1356) grouped with Lasiodiplodia pseudotheobromae, 13 isolates were closely related to Diplodia seriata $(=B$. obtusa $)$, but grouped clearly distinct from it, and the remaining isolate formed a distinct branch amongst clades representing Dothiorella and Spencermartinsia species respectively.

Botryosphaeria dothidea occurred as an endophyte in four different native Myrtaceae species and two Eucalyptus species (Table 1) and was also associated with a stem canker on E. maidenii. Isolates belonging to the $N$. parvum-N. ribis complex were found in five distinct Eucalyptus species and eight native Myrtaceae species. These were obtained from asymptomatic plant tissue except isolates UY1050 and UY1366, which were obtained from stem cankers on E. globulus and Blepharocalyx salicifolius, respectively. Neofusicoccum eucalyptorum was found as an endophyte in six different Eucalyptus species and two species of native Myrtaceae (Table 1). It was also associated with a stem canker in Myrceugenia glaucescens. Lasiodiplodia pseudotheobromae was found associated with a stem canker on Myrcianthes pungens. In addition, isolates of the unknown Diplodia sp. were obtained from Myrtaceous trees, but not found on Eucalyptus samples. Most of these isolates were obtained from healthy tissue with the exception of isolate UY1263 which was from a stem canker observed on Myrciaria tenella. The isolate of the unidentified Spencermartinsia sp. was found as an endophyte in the native Myrtaceous tree, Hexachlamis edulis (Table 1). The DNA sequence alignments of the ITS, EF1- $\alpha$ and the combined dataset of both regions (tree parameters in Table 2) showed consistency among trees and confirmed that the group of isolates in the Diplodia sp. cluster obtained from native trees grouped consistently in a strongly supported distinct clade (Fig. 2). Additionally, isolate UY672 grouped separately from other Dothiorella and Spencermartinsia species with significant sequence divergence between it and the closest related clade (Spencermartinsia sp. ICMP16819 and ICMP16824).

Table 2. Tree parameters obtained from the maximum parsimony analysis of the ITS region, partial EF1- $\alpha$ gene and combined dataset of both regions.

\begin{tabular}{llccccccc}
\hline Dataset & $\begin{array}{l}\text { Total } \\
\text { characters }\end{array}$ & $\begin{array}{l}\text { Parsinony- } \\
\text { uninformative }\end{array}$ & $\begin{array}{l}\text { Constant } \\
\text { charscters }\end{array}$ & $\begin{array}{l}\text { Parsimony } \\
\text { informative }\end{array}$ & $\begin{array}{l}\text { Tree } \\
\text { Length }\end{array}$ & $\begin{array}{l}\text { Consistency } \\
\text { Index }\end{array}$ & $\begin{array}{l}\text { Retention } \\
\text { Index }\end{array}$ & $\begin{array}{l}\text { Homoplasy } \\
\text { Index }\end{array}$ \\
\hline ITS & 556 & 33 & 367 & 156 & 426 & 0.716 & 0.937 \\
EF $1-\alpha$ & 352 & 26 & 93 & 233 & 659 & 0.700 & 0.924 \\
Combined & 908 & 59 & 460 & 389 & 1,111 & 0.689 & 0.924 \\
\hline
\end{tabular}




\section{Pathogenicity tests}

Selected isolates representing all the Botryosphaeriaceae species found on Myrtaceae hosts were able to produce lesions within a week after inoculation on stems of E. grandis seedlings (Fig. 3). Significant differences in lesion length were observed among isolates of different species, and isolate UY1356 identified as L. pseudotheobromae collected from Myrcianthes pungens showed the largest lesions $(\mathrm{P}<0.05$; Fig. 4). Isolates of the unknown Diplodia sp. and Spencermartinsia $\mathrm{sp}$. produced lesions not significantly different from the controls. Similar results were observed for inoculations with $B$. dothidea.
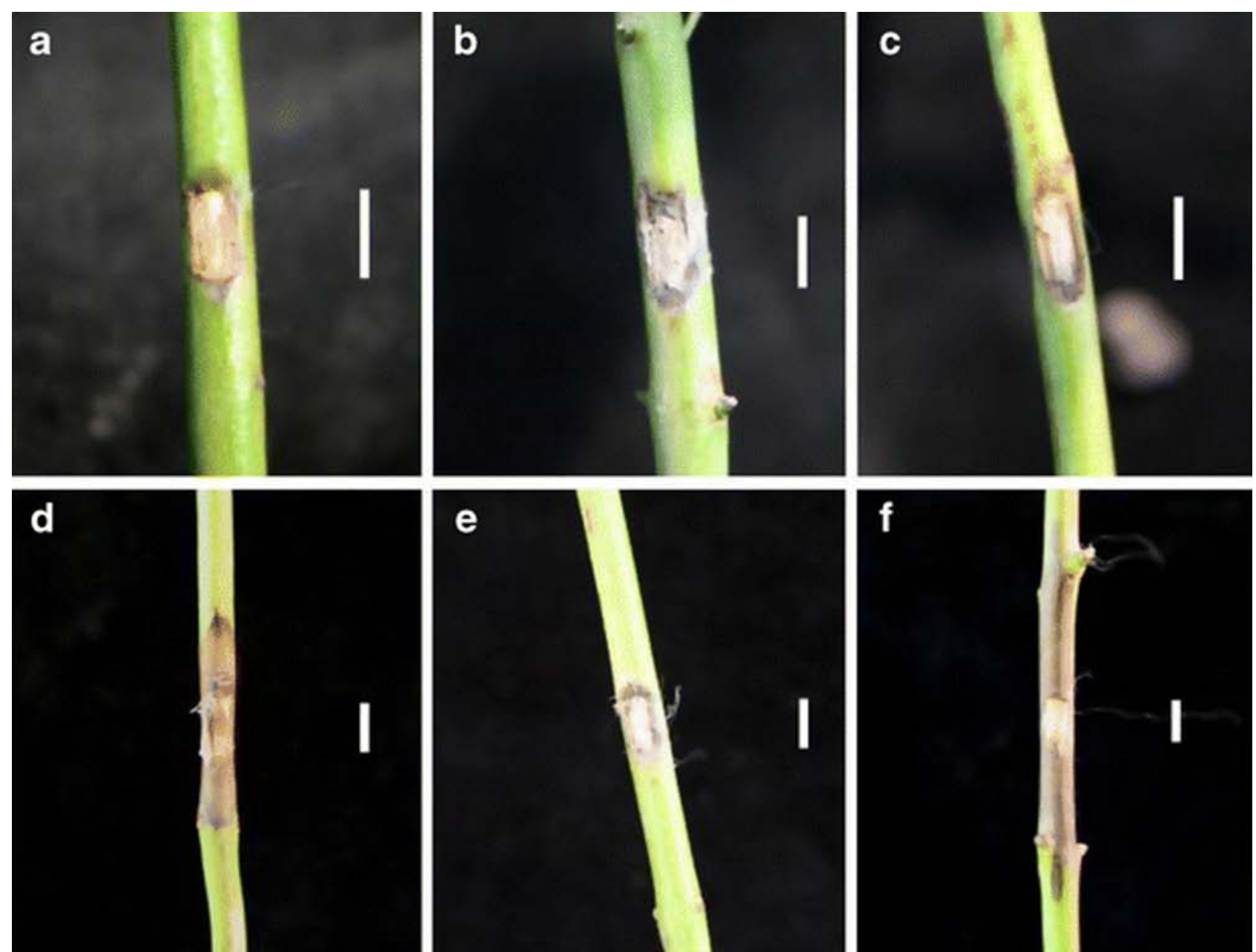

Fig. 3. Stem lesions observed 1 week after inoculation of selected isolates on 4-month old $E$. grandis seedlings, a. Control, b. Diplodia pseudoseriata (isolate UY788), c. Spencermartinsia uruguayensis (isolate UY672), d. N. parvum/N. ribis (isolate UY543), e. B. dothidea (isolate UY719) and f. L. pseudotheobromae (isolate UY1356). Scale bar $=5 \mathrm{~mm}$. 


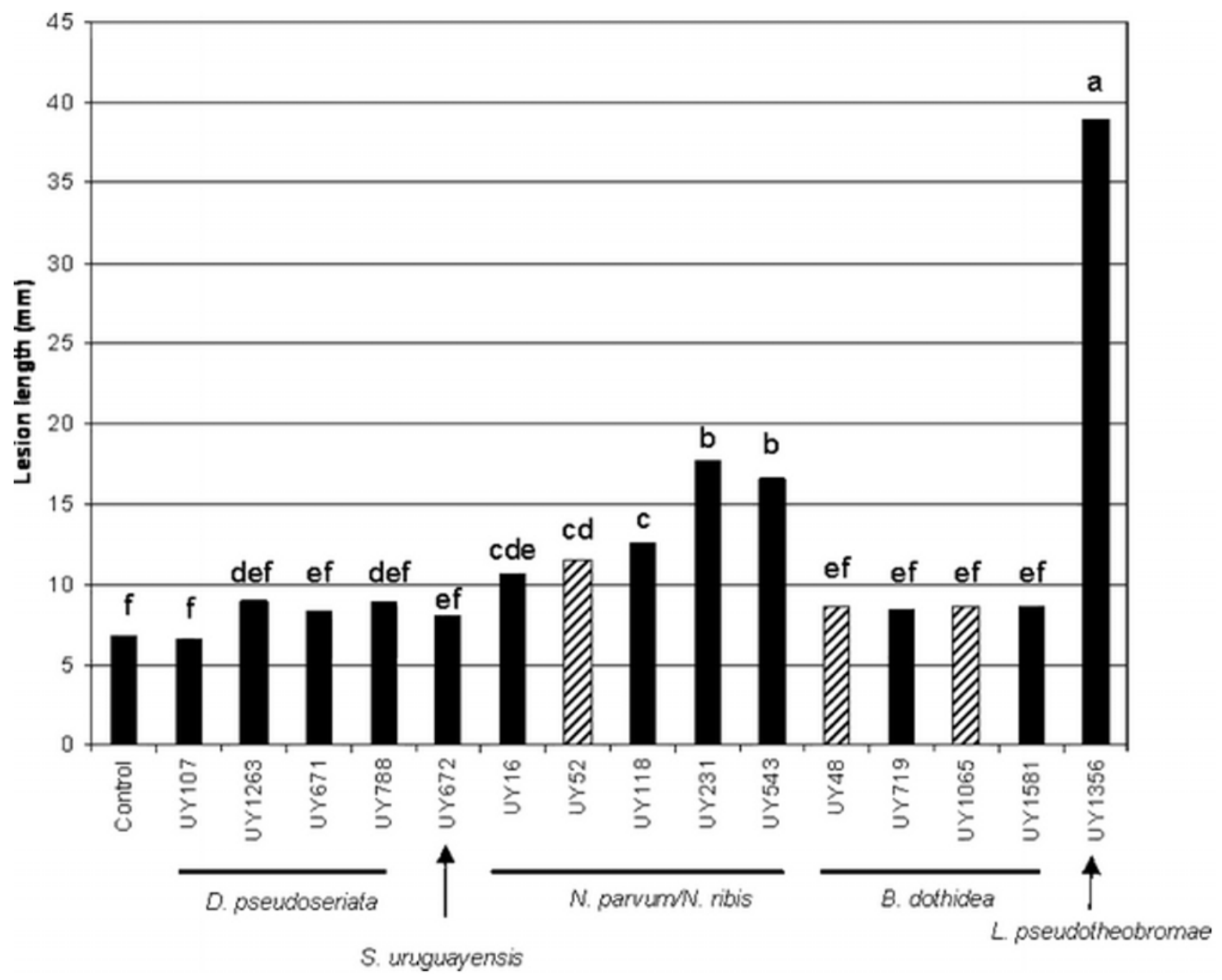

Fig. 4. Lesion length (average of 10 replicates) observed 1 week after inoculation on stems of $E$. grandis for selected isolates of Botryosphaeriaceae species found on Myrtaceae hosts in Uruguay. Letters indicate mean separation based on LSD $(\mathrm{P}=0.05)$. Isolates UY52, UY48 and UY1065 shown with downward diagonal bars were obtained from Eucalyptus and randomly selected and included in this study for reference.

Isolates were grouped by species and mean lesion length for species inoculated were compared using orthogonal contrasts, although only a limited number of isolates were analyzed for some species. Results indicated that L. pseudotheobromae was the most pathogenic species followed by isolates of the N. parvum-N. ribis complex, whereas the unidentified Diplodia sp. and Spencermartinsia sp. together with $B$. dothidea showed no differences $(\mathrm{P}>0.10)$ compared to the control treatment (Fig. 5). Stem diameter determined 1 week after inoculation ranged between 3 and $4 \mathrm{~mm}$ and showed no significant differences among treatments (data not shown), indicating there was no effect associated with seedling size. 


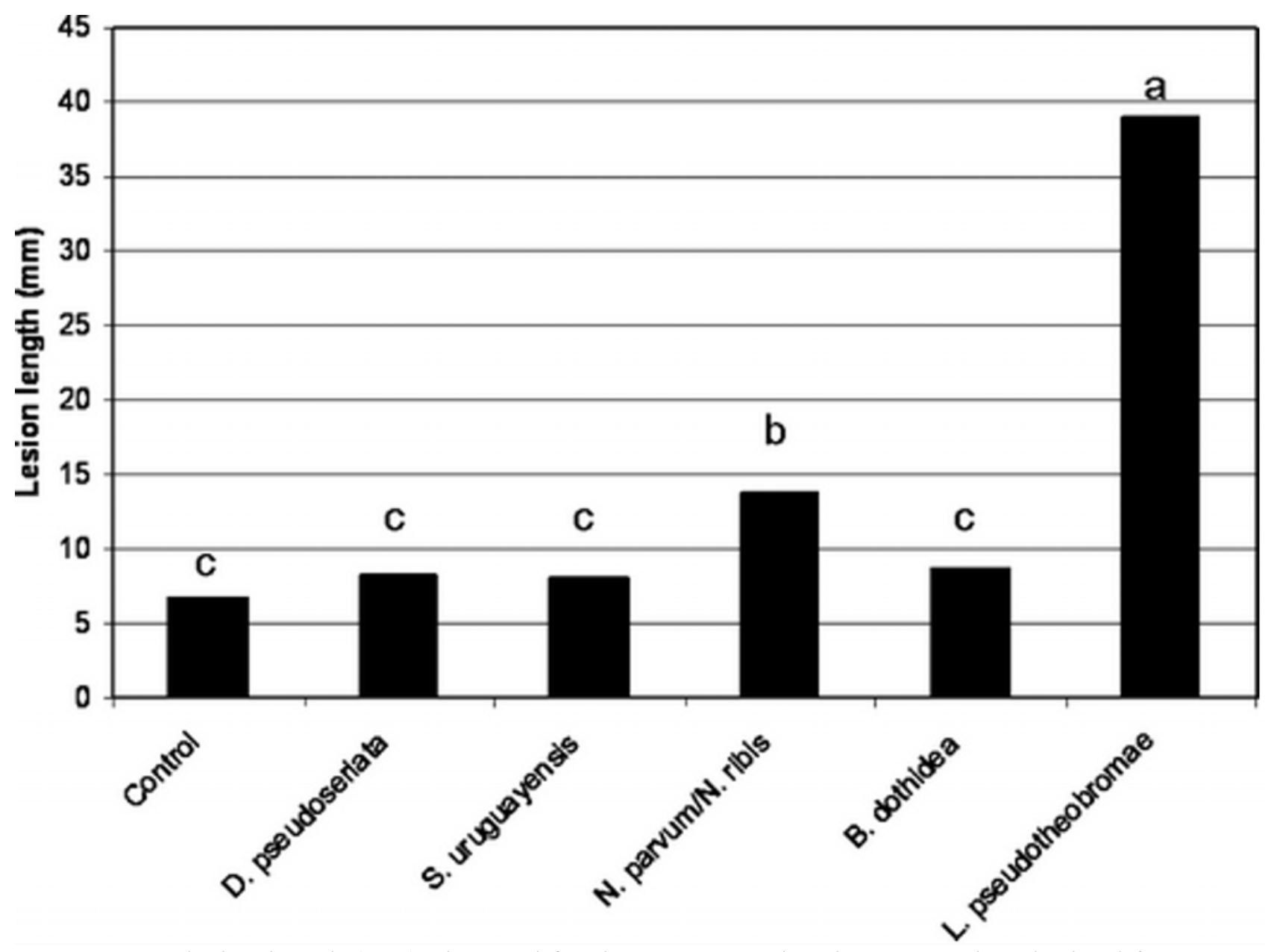

Fig. 5. Mean lesion length ( $\mathrm{mm}$ ) observed for those Botryosphaeriaceae species obtained from native Myrtaceae hosts 1 week after inoculated on E. grandis stems. Isolates were grouped by species and mean comparison between groups was performed using orthogonal contrasts. Different letters indicate significant differences $(\mathrm{P}<0.001)$.

\section{Taxonomy}

Based on morphology and combined multiple gene genealogies, we conclude that the isolates representing the unidentified Diplodia sp. and Spencermartinsia sp. represent previously undescribed species in the Botryosphaeriaceae. We provide the following description for these two species.

Diplodia pseudoseriata C.A. Pérez, R.A. Blanchette, B. Slippers \& M.J. Wingfield, sp. nov. (Fig. $6)$. 


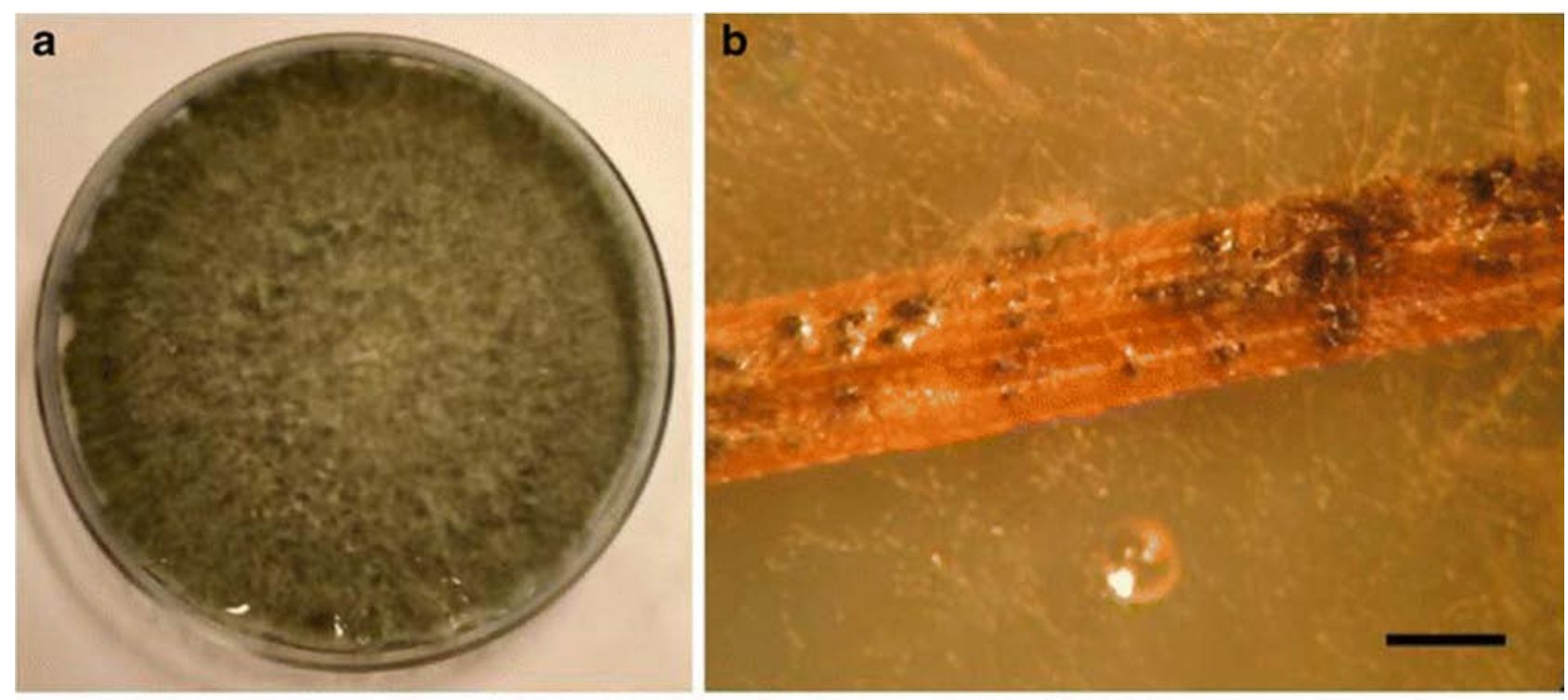

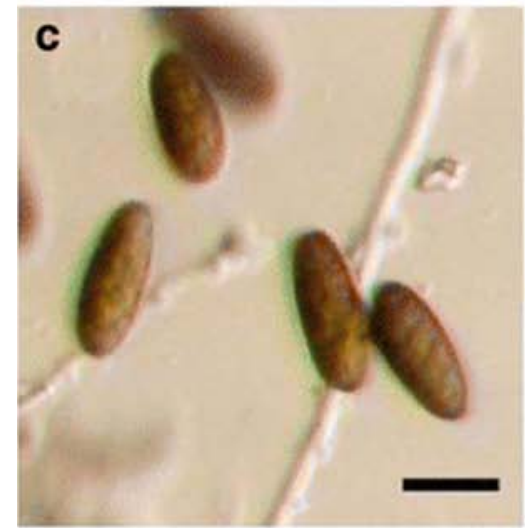

f

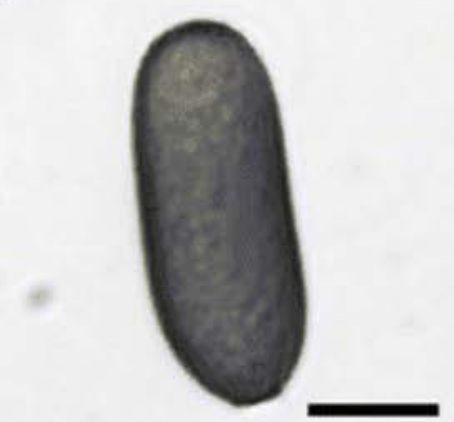

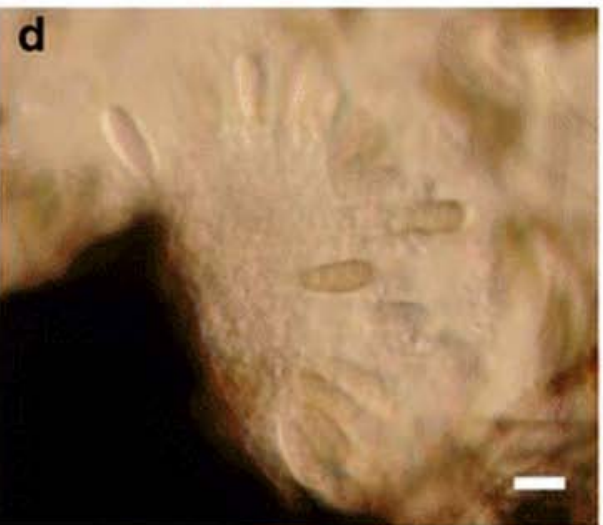

g

h

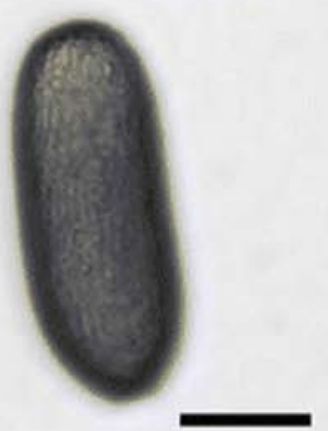

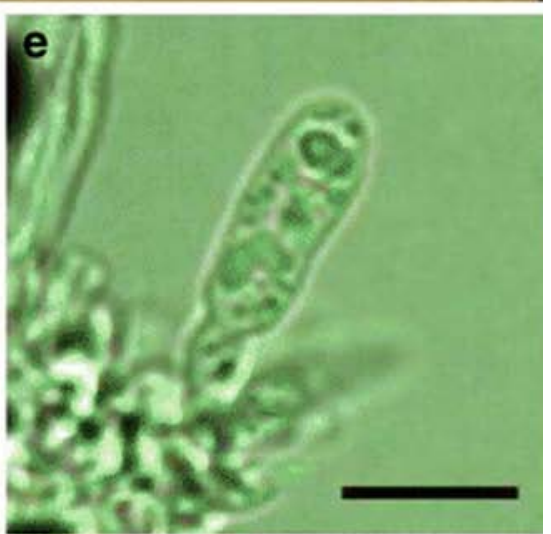

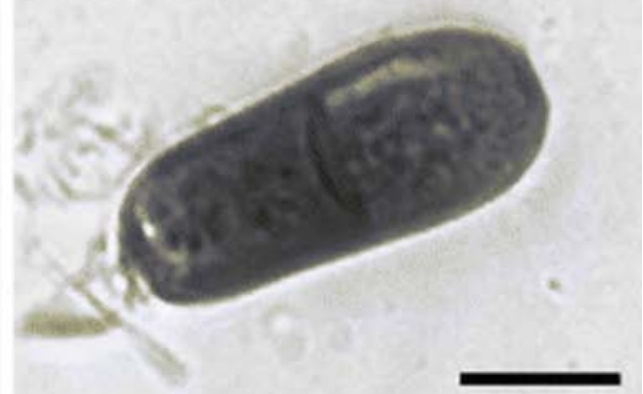

Fig. 6. Micrographs of fruiting structures of Diplodia pseudoseriata a. 1 week old colony grown on PDA; b. semi-immersed and superficial pycnidia formed on pine needles; $c$. brown mature conidia; d. conidiophores with immature conidium; e. conidiogenous cell with immature conidium; f. and g. conidium with obtuse apex and truncate base photographed at two different levels of focus to show the conidium wall with a smooth outer surface (f) and the roughened inner surface (g); h. 1-septate conidium. Scale bars: $\mathrm{b}=1 \mathrm{~mm} ; \mathrm{c}-\mathrm{e}=20 \mu \mathrm{m} ; \mathrm{f}-\mathrm{h}=10 \mu \mathrm{m}$

\section{MycoBank: MB 513545}

Etymology: Named for its resemblance to $D$. seriata.

Pycnidia (formed in culture on sterilized pine needles) semi-immersed or superficial, solitary, globose, black, covered by mycelium, up to $430 \mu \mathrm{m}$ diam. Conidiogenous cells cylindrical, discrete, producing a single conidium at the tip, with no evident annelations. Conidia (23-) 25.5-26.5 ($30.5) \times(10-)) 11.5-12(-14) \mu \mathrm{m}$, initially hyaline becoming dark brown, wall externally smooth, 
roughened on the inner surface, sometimes 1-septate, ovoid, apex obtuse, base truncate.

Pycnidia (in foliis sterilibus pini culta) subimmersa vel superficialia, solitaria globosa nigra mycelio tecta usque ad $430 \mu \mathrm{m}$ diametro. Cellulae conidiogenae cylindricae discretae apice conidium unicum sine annelationibus manifestis facientes. Conidia (23-) 25.5-26.5 (-30.5) $\times(10-) 11.5-12(-$ 14) $\mu \mathrm{m}$ primo hyalina atrobrunnescentia parietibus extus laevibus, intus exasperatis, interdum semel septata ovoidea apice obtusa basi truncata.

Teleomorph: unknown

Hosts: Acca sellowiana, Blepharocalyx salicifolius, Eugenia uniflora, Eugenia involucrata, Hexachlamis edulis, Myrceugenia euosma, Myrciaria tenella, and Myrcianthes cisplatensis.

Known distribution: Uruguay

Specimen examined: URUGUAY. Paysandu, Guaviyu. Isolated from asymptomatic twig of Blepharocalyx salicifolius, August 2006, C. Perez, holotype PREM 60264, living cultures UY788, CMW26771, CBS 124906.

Additional specimens: URUGUAY. Paysandu, Guaviyu. Isolated from asymptomatic twig of Myrcianthes cisplatensis, asymptomatic twig of Hexachlamis edulis, and expanding lesion of stem canker on Myrciaria tenella, August 2006, C. Perez, paratype, living cultures UY107/CMW26742, herbarium PREM 60265, UY671/CMW26762/CBS 124907, herbarium PREM 60266, UY1263/CMW26788, herbarium PREM 60267, respectively.

Spencermartinsia uruguayensis C.A. Pérez, R.A. Blanchette, B. Slippers \& M.J. Wingfield, sp. nov. (Fig. 7) 


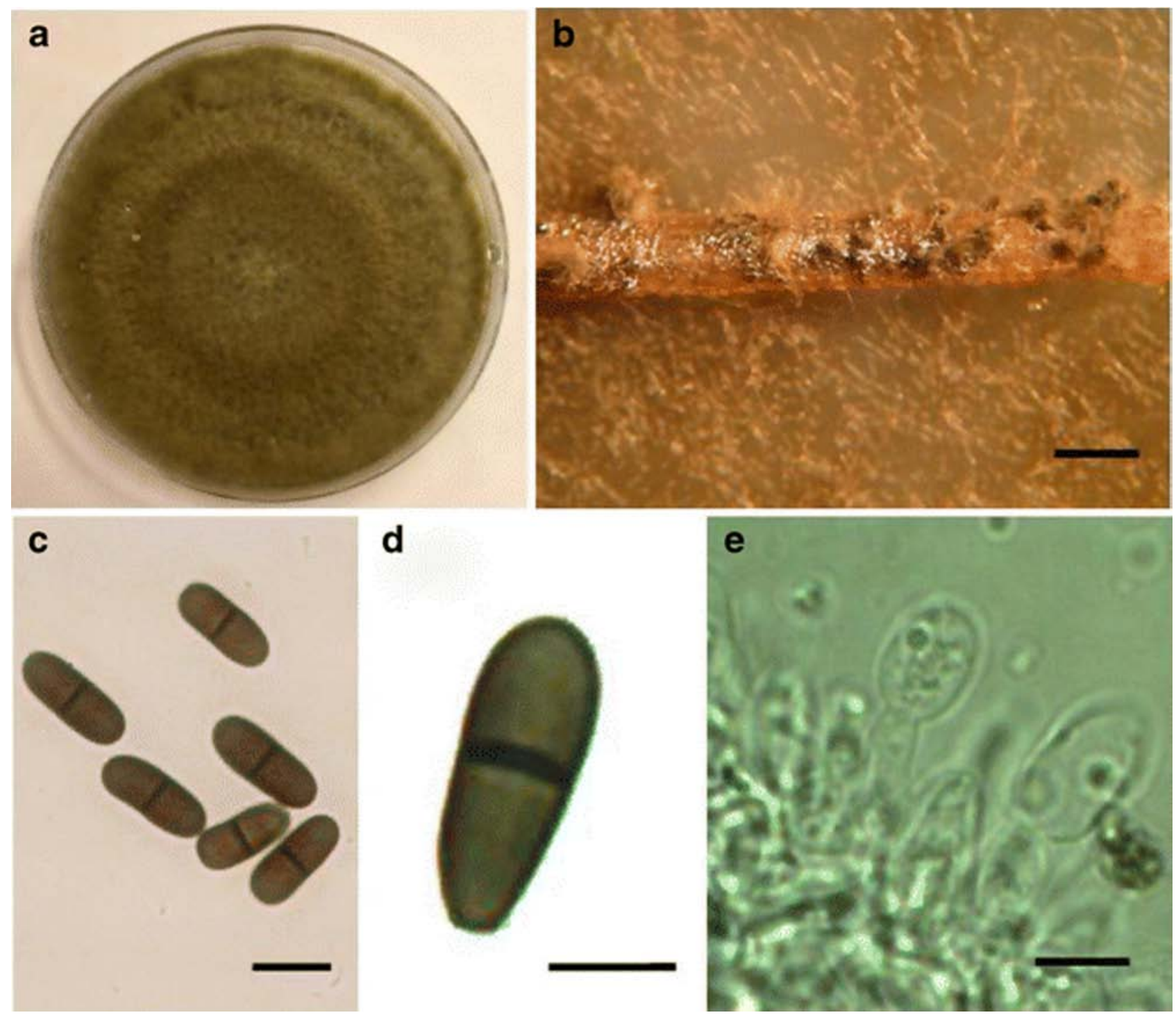

Fig. 7. Micrographs of fruiting structures of Spencermartinsia uruguayensis a. 1 week old colony grown on PDA; b. superficial pycnidia formed on pine needles; c. dark brown walled conidia, 1septate; d. conidium slightly constricted at the septum, with broadly rounded apex and truncate base; e. conidiophores with immature conidia. Scale bars: $b=1 \mathrm{~mm} ; \mathrm{c}=20 \mu \mathrm{m}$; $\mathrm{d}-\mathrm{e}=10 \mu \mathrm{m}$

MycoBank: MB 514538

Etymology: Name refers to the country Uruguay where this fungus was first found.

Pycnidia (formed in culture on sterilized pine needles) superficial, solitary, globose, black, nonpapillate, covered by mycelium, up to $350 \mu \mathrm{m}$ diam. Conidiogenous cells hyaline, subcylindrical. Conidia (17-) 22-22.5 (-26.5) × (7-) 9-9.5 (-12) $\mu \mathrm{m}$, dark brown walled, 1-septate, slightly constricted at the septum, ovoid with broadly rounded apex and truncate base.

Pycnidia (in foliis sterilibus pini culta) superficialia, solitaria globosa nigra non papillata, mycelio tecta usque ad $350 \mu \mathrm{m}$ diametro. Cellulae conidiogenae hyalinae subcylindricae. Conidia (17-) $22-$ $22.5(-26.5) \times(7-) 9-9.5(-12) \mu \mathrm{m}$, parietibus atrobrunneis, semel septata in septo parum constricta, ovoidea apice late rotundata basi truncata.

Teleomorph: unknown

Host: Hexachlamis edulis. 
Known distribution: Uruguay

Specimen examined: URUGUAY. Paysandu, Tres Bocas. Endophytic infections on twigs of Hexachlamis edulis, August 2006, C. Perez, holotype PREM 60268, living cultures UY672, CMW26763, CBS 124908.

\section{Discussion}

Results of this study provide evidence that a diverse group of Botryosphaeriaceae occurs on both introduced Eucalyptus and native Myrtaceae trees in Uruguay. Botryosphaeria dothidea, $N$. eucalyptorum and members of the N. parvum-N. ribis complex were isolated from both Eucalyptus and native Myrtaceae, demonstrating biotic exchange between native and introduced Myrtaceae. In contrast, L. pseudotheobromae was restricted to Myrcianthes pungens. In addition, two novel species of the Botryosphaeriaceae were isolated from Myrtaceae native to Uruguay. Of these, $D$. pseudoseriata occurred in healthy tissue of six different Myrtaceae species and it was also associated with a stem canker observed on Myrciaria tenella. Spencermartinsia uruguayensis was obtained from endophytic infections on Hexachlamis edulis.

Pathogenicity tests showed that isolates obtained from native Myrtaceae are able to infect Eucalyptus. Of these, isolates in the N. parvum-N. ribis group and L. pseudotheobromae were highly pathogenic, killing a significant area of stem tissue and resulting in large cankers. In contrast, D. pseudoseriata and $S$. uruguayensis showed no differences from the control $(\mathrm{P}>0.10)$ and this may indicate that these isolates are not Eucalyptus pathogens. To the best of our knowledge $L$. pseudotheobromae has not been found occurring on Eucalyptus in Uruguay and these results highlight the importance of considering native forests when assessing the potential for host shifts between pathogens.

Botryosphaeria dothidea was confirmed as an endophyte in Eucalyptus and native Myrtaceae hosts, but it was also found associated with stem cankers in Eucalyptus. This fungus was previously reported as an endophyte infecting Eucalyptus spp. (Bettucci and Alonso 1997; Smith et al. 1996) and also causing stem cankers on Eucalyptus in Uruguay (Balmelli et al. 2004) and other countries (Smith et al. 1994). In addition, Bettucci et al. (2004) reported the presence of endophytic $B$. dothidea in Myrceugenia glaucescens, a myrtaceous tree native to Uruguay. However, identifications of Botryosphaeriaceae prior to the application of DNA sequence comparisons must be considered with some circumspection as the name used most probably refers to a suite of different species and not one fungus. Thus, some of the isolates previously considered to be $B$. dothidea have subsequently been shown to represent $N$. parvum and N. ribis (Slippers et al. 2004a). Using a modern taxonomic concept for Botryosphaeriaceae, $B$. dothidea has rarely been isolated from Eucalyptus spp. and it has been suggested that this fungus may not be an important pathogen of these trees (Slippers et al. 2004b; Pavlic et al. 2007). Consistent with this view, B. dothidea was not the most common Botryosphaeriaceae species isolated from Eucalyptus samples in the present study. Inoculation tests on E. grandis also showed that this fungus had a very low level of pathogenicity to these trees.

Neofusicoccum eucalyptorum has recently been shown to infect native Myrtaceae in Uruguay and cross pathogenicity was also shown to occur (Pérez et al. 2009). Prior to that study, this fungus was reported in Uruguay as an endophyte in E. globulus and it was also collected from bark lesions (Alonso 2004). This fungus was found in six different Eucalyptus species and it also represented $63 \%$ of the Botryosphaeriaceae isolated in this study. Smith et al. (2001) considered the pathogenicity of several isolates of $N$. eucalyptorum and showed that this fungus was consistently more pathogenic than $B$. dothidea. 
It was not surprising to find isolates in the N. parvum-N. ribis complex in this study, as members of this group are commonly known to occur on Eucalyptus and other hosts including certain Myrtaceae trees worldwide (Barber et al. 2005; Burgess et al. 2005; Gure et al. 2005; Mohali et al. 2007; Pavlic et al. 2007; Slippers et al. 2004b). Slippers et al. (2004a) used a multiple gene genealogy approach to confirm that $N$. parvum and $N$. ribis represents different species. They also recommend caution when distinguishing between these two species based on morphological or single locus DNA sequence data. Preliminary evidence using ITS and EF-1 $\alpha$ data (data not shown) could not conclusively resolve their identity and they possibly represent a distinct cryptic species in this complex. Pavlic et al. (2009) provided evidence confirming that N. parvum and N. ribis represent distinct species and also reported the presence of cryptic species into this complex. Alonso (2004) reported the presence of $N$. ribis on E. globulus based on the morphology and comparisons of sequence data for the ITS region of the rDNA operon, but further analyses are required to confirm this report, most likely using RPB2 sequences in combination with ITS sequences as proposed by Pavlic et al. (2009).

The $N$. parvum-N. ribis group warrants further investigation to resolve the correct identification of isolates obtained in this study. This is especially so, because it was one of the most pathogenic species in this and previous studies (Pavlic et al. 2007; Mohali et al. 2009). Our results indicate that representatives of the $N$. parvum-N. ribis complex are widely present in both Eucalyptus and native Myrtaceae. The clear association of this complex with stem cankers on both hosts, together with the pathogenicity observed in inoculation tests, suggests that this group represents the most significant threat to trees in Uruguay.

Interestingly, L. pseudotheobromae was found in a single sample association with a stem canker on the native Uruguayan tree, Myrcianthes pungens. Inoculation tests also showed that it is pathogenic to Eucalyptus. This species, along with L. parva, has recently been shown to be a cryptic species previously misidentified as $L$. theobromae (Alves et al. 2008). Thus, previous references to $L$. theobromae must be considered with caution because they may actually refer to $L$. pseudotheobromae or other species.

Lasiodiplodia theobromae sensu lato has been referred to as a widely distributed fungus in tropical and subtropical regions and is reported to infect more than 500 plant species (Punithalingam 1976). This fungus has been associated with shoot blight, die-back, wood discoloration, and stem cankers on a diverse group of hosts (Mohali et al. 2005). Although it is considered an opportunistic pathogen, it has been demonstrated to have a devastating effect on stressed plants (Müllen et al. 1991). Pavlic et al. (2007) concluded that L. theobromae isolated from Syzygium cordatum, a Myrtaceae species native to South Africa, was the most pathogenic Botryosphaeriaceae species to the Eucalyptus clone tested in that study. Mohali et al. (2005) further demonstrated that there was no evidence of host specificity for this fungus and a high level of gene flow was found between populations occurring on different hosts.

Diplodia pseudoseriata was widely distributed in native Myrtaceae forests in Uruguay. Despite its common occurrence in close proximity to Eucalyptus plantations, it was not detected on this host in this study. The weak reactions observed after inoculation on E. grandis also suggest that this species is not pathogenic to this host. This fungus, thus far only known from native Myrtaceae in Uruguay, is possibly native to this region and unable to infect Eucalyptus. It is the only Diplodia species known from native Myrtaceae, and there are few records of this fungus on Angiosperms in the Southern Hemisphere (De Wet et al. 2008; Slippers and Wingfield 2007).

The presence of $S$. uruguayensis on the native H. edulis is intriguing. Despite the examination of a very large number of Myrtaceae samples, this species was found on a single sample suggesting that 
it is a rare fungus on this host and in the area. This may indicate that this species was only very recently introduced, or if it is native to Uruguay, it may be more common on non-Myrtaceae hosts. Inoculation results suggest that it has only minor levels of pathogenicity.

The study here used traditional techniques to isolate botryosphaeriaceous endophytes. It is therefore likely that only quickly growing taxa were isolated and those that are slow growing or cannot grow in culture were not detected (Hyde and Soytong 2008). It would be interesting to apply techniques where DNA is isolated directly from samples (e.g. Guo et al. 2000, 2001; Nikolcheva and Bärlocher 2005; Duong et al. 2006; Seena et al. 2008; Tao et al. 2008; Curlevski et al. 2009; Nilsson et al. 2009), to reveal if other botryosphaericeous endophytes are present.

Although no extensive diseases outbreaks caused by Botryosphaeriaceae have been observed in Uruguay, the situation could change. The explosive expansion of Eucalyptus plantations and the association of Botryosphaeriaceae with extreme weather conditions, primarily drought, along with the additional pressure and stresses from other pathogens, raise concerns about the threat of Botryosphaeriaceae-related diseases worldwide (Desprez-Loustau et al. 2006; Slippers and Wingfield 2007). Results presented here provide a foundation to monitor the development of such diseases on native and non-native Myrtaceae in Uruguay in the future. In particular it will be important to study the gene flow between both hosts of B. dothidea, $N$. eucalyptorum and the $N$. parvum $-N$. ribis complex to better assist breeding programs aimed at elevating resistance to diseases. In addition, discovery off the relatively aggressive species, L. pseudotheobromae, on a native host demonstrates the relevance of surveying native forest trees for early detection of potential threats to Eucalyptus plantations.

\section{Acknowledgments}

This work was partially funded by INIA-Uruguay, project FPTA221. We also thank Forestal Oriental, Rivermol, Stora Enso and Weyerhaeuser financial and logistic support. We appreciate the assistance of Andrés Berrutti, Ana Terzaghi, Oscar Bentancur, Sofia Simeto, Gustavo Balmelli, Hugh Glen and Marieka Gryzenhout.

\section{Literature Cited}

Alonso R (2004) Estudio de Botryosphaeria spp. en Eucalyptus globulus en Uruguay: endofitismo o patogenicidad? (Studies of Botryosphaeria spp. in Eucalyptus globulus in Uruguay: endophytism or pathogenicity?). Tesis de Maestría en Biología. PEDECIBA, Uruguay, p 52.

Alves A, Crous PW, Correia A, Phillips AJL (2008) Morphological and molecular data reveal cryptic speciation in Lasiodiplodia theobromae. Fungal Divers 28:1-13.

Balmelli G, Resquin F (2005) Efecto de enfermedades del fuste en Eucalyptus globulus. Revista Forestal 27:9-14.

Balmelli G, Marroni V, Altier N, Garcia R (2004) Potencial del mejoramiento genético para el manejo de enfermedades en Eucalyptus globulus. INIA, Serie Técnica, 143.

Barber P, Burgess T, Hardy G, Slippers B, Keane P, Wingfield M (2005) Botryosphaeria species from Eucalyptus in Australia are pleoanamorphic, producing Dichomera synanamorphs in culture. Mycol Res 109:1347-1363.

Barnard E, Geary T, English J, Gilly S (1987) Basal cankers and coppice failure of Eucalyptus 
grandis in Florida. Plant Dis 71:358-361.

Bettucci L, Alonso R (1997) A comparative study of fungal populations in healthy and symptomatic twigs of Eucalyptus grandis in Uruguay. Mycol Res 101:1060-1064.

Bettucci L, Simeto S, Alonso R, Lupo S (2004) Endophytic fungi of twigs and leaves of three native species of Myrtaceae in Uruguay. Sydowia 56:8-23.

Brussa CA, Grela IA (2007) Flora arbórea del Uruguay con énfasis en las especies de Rivera y Tacuarembo. COFUSA. Mosca. Montevideo, Uruguay, p 543.

Burgess T, Barber P, Hardy G (2005) Botryosphaeria spp. associated with eucalypts in Western Australia, including the description of Fusicoccum macroclavatum sp. nov. Australas Plant Pathol 34:557-567.

Burgess TI, Sakalidis ML, Hardy GEStJ (2006) Gene flow of the canker pathogen Botryosphaeria australis between Eucalyptus globulus plantation and native eucalypt forests in Western Australia. Austral Ecology 31:559-566.

Coutinho T, Wingfield MJ, Alfenas A, Crous P (1998) Eucalyptus rust: a disease with the potential for serious international implications. Plant Dis 82:819-825.

Curlevski NJA, Chambers SM, Anderson IC, Cairney JWG (2009) Identical genotypes of an ericoid mycorrhiza-forming fungus occur in roots of Epacris pulchella (Ericaceae) and Leptospermum polygalifolium (Myrtaceae) in an Australian sclerophyll forest. FEMS Microbiol Ecol 67:411-420.

Desprez-Loustau ML, Marcais B, Nageleisen LM, Piou D, Vannini A (2006) Interactive effects of drought and pathogens in forest trees. Ann For Sci 63:597-612.

De Wet J, Slippers B, Preisig O, Wingfield BD, Wingfield MJ (2008) Phylogeny of the Botryosphaeriaceae reveals patterns of host association. Mol Phylogenet Evol 46:116-126.

Duong LM, Jeewon R, Lumyong S, Hyde KD (2006) DGGE coupled with ribosomal DNA phylogenies reveal uncharacterized fungal phylotypes on living leaves of Magnolia liliifera. Fungal Divers 23:121-138.

Farris JS, Kallersjo M, Kluge AG, Bult C (1995) Testing significance of incongruence. Cladistics 10:315-319.

Gomez KA, Gomez AA (1984) Statistical procedures for agricultural research, 2nd edn. Wiley Interscience, USA, p 680.

Guo LD, Hyde KD, Liew ECY (2000) Identification of endophytic fungi from Livistonia chinensis based on morphology and rDNA sequences. New Phytol 147:617-630.

Guo LD, Hyde KD, Liew ECD (2001) Detection and taxonomic placement of endophytic fungi within frond tissues of Livistona chinensis based on rDNA sequences. Mol Phylogenet Evol 20:113 .

Gure A, Slippers B, Stenlid J (2005) Seed-borne Botryosphaeria spp. from native Prunus and Podocarpus trees in Ethiopia, with a description of the anamorph Diplodia rosulata sp. nov. Mycol Res 109:1005-1014. 
Hillis DM, Bull JJ (1993) An empirical test of bootstrapping as a method for assessing confidence in phylogenetic analysis. Syst Biol 42:142-152.

Huang WY, Cai YZ, Hyde KD, Corke H, Sun M (2008) Biodiversity of endophytic fungi associated with 29 traditional Chinese medicinal plants. Fungal Divers 33:61-75.

Huelsenbeck JP, Bull JJ, Cunningham CW (1996) Combining data in phylogenetic analysis. TREE 11:152-158.

Hyde KD, Soytong K (2008) The fungal endophyte dilemma. Fungal Divers 33:163-173.

Katoh K, Kuma K, Toh H, Miyata T (2005) MAFFT version 5: improvement in accuracy of multiple sequence alignment. Nucleic Acids Res 33:511-518.

Lazzizera C, Frisullo S, Alves A, Lopes J, Phillips AJL (2008) Phylogeny and morphology of Diplodia species on olives in southern Italy and description of Diplodia olivarum sp. nov. Fungal Divers 31:63-71.

Mohali S, Burgess TI, Wingfield MJ (2005) Diversity and host association of the tropical tree endophyte Lasiodiplodia theobromae revealed using simple sequence repeat markers. Forest Pathol 35:385-396.

Mohali S, Slippers B, Wingfield M (2007) Identification of Botryosphaeriaceae from Eucalyptus, Acacia, and Pinus in Venezuela. Fungal Divers 25:103-125.

Mohali S, Slippers B, Wingfield M (2009) Pathogenicity of seven species of Botryosphaeriaceae on Eucalyptus clones in Venezuela. Australas Plant Pathol 38:135-140.

Müllen JM, Gilliam CH, Hagen AK, Morgan Jones G (1991) Lasiodiplodia theobromae cancer of dogwood, a disease influenced by drought stress or cultivar selection. Plant Dis 75:886-889.

Nikolcheva LG, Bärlocher F (2005) Seasonal and substrate preferences of fungi colonizing leaves in streams: traditional versus molecular evidence. Environ Microbiol 7:270-280.

Nilsson RH, Ryberg M, Abarenkov K, Sjökvist E, Kristiansson E (2009) The ITS region as a target for characterization of fungal communities using emergent sequencing technologies. FEMS Microbiol Lett 296:97-101.

Nylander JA (2004) MrModeltest v2.2. Program distributed by the author. Evolutionary Biology Centre, Uppsala University, Uppsala.

Old K, Davison E (2000) Canker diseases of eucalypts. In: Keane P, Kile G, Podger F, Brown B (eds) Diseases and Pathogens of Eucalypts. CSIRO Publishing, Collingwood, Australia, pp 247257.

Old K, Gibbs R, Craig I, Myers B, Yuan Z (1990) Effect of drought and defoliation on the susceptibility of eucalypts to cankers caused by Endothia gyrosa and Botryosphaeria ribis. Aust $\mathrm{J}$ Bot 38:571-581.

Pavlic D, Slippers B, Coutinho T, Wingfield M (2007) Botryosphaeriaceae occurring on native Syzygium cordatum in South Africa and their potential threat to Eucalyptus. Plant Pathol 56:624636. 
Pavlic D, Slippers B, Coutinho T, Wingfield M (2009) Multiple gene genealogies and phenotypic data reveal cryptic species of the Botryosphaeriaceae: a case study on the Neofusicoccum parvum/ N. ribis complex. Mol Phylogenet Evol 51:259-268.

Pérez CA, Wingfield MJ, Slippers B, Altier NA, Blanchette RA (2009) Neofusicoccum eucalyptorum, a Eucalyptus pathogen, on native Myrtaceae in Uruguay. Plant Pathol 58:964-970.

Posada D, Crandall KA (1998) MODELTEST: testing the model of DNA substitution. Bioinformatics 14:817-818.

Punithalingam E (1976) Botryodiplodia theobromae. CMI Descriptions of pathogenic fungi and bacteria. Commonwealth Mycological Institute, Kew, Surrey, No 519.

Pusey P (1989) Influence of water stress on susceptibility of nonwounded peach bark to Botryosphaeria dothidea. Plant Dis 73:1000-1003.

Rodas CA, Roux RJ, van Wyk M, Wingfield BD, Wingfield MJ (2008) Ceratocystis neglecta sp. nov., infecting Eucalyptus trees in Colombia. Fungal Divers 28:73-84.

Ronquist F, Huelsenbeck JP (2003) MrBayes3: Bayesian phylogenetic inference under mixed models. Biometrics 19:1572-1574.

Sakalidis M (2004) Resolving the Botryosphaeria ribis-B. parva species complex; a molecular and phenotypic investigation. Honors thesis. School of Biological Sciences and Biotechnology, Murdoch University, Western Australia.

Seena S, Wynberg N, Bärlocher F (2008) Fungal diversity during leaf decomposition in a stream assessed through clone libraries. Fungal Divers 30:1-14.

Seixas C, Barreto R, Alfenas A, Ferreira F (2004) Cryphonectria cubensis on an indigenous host in Brazil: a possible origin for Eucalyptus canker disease? Mycologist 18:39-45.

Simeto S, Balmelli G, Altier N, Dini B, Bennadji Z (2007) Desarrollo de protocolos de inoculación artificial para la caracterización sanitaria de Eucalyptus globulus. INIA, Uruguay, p 26, Serie Técnica 169.

Slippers B, Wingfield MJ (2007) Botryosphaeriaceae as endophytes and latent pathogens of woody plants: diversity, ecology and impact. Fungal Biol Rev 21:90-106.

Slippers B, Crous P, Denman S, Coutinho T, Wingfield B, Wingfield M (2004a) Combined multiple gene genealogies and phenotypic characters differentiate several species previously identified as Botryosphaeria dothidea. Mycologia 96:83-101.

Slippers B, Fourie G, Crous P, Coutinho T, Wingfield B, Carnegie A, Wingfield M (2004b) Speciation and distribution of Botryosphaeria spp. on native and introduced Eucalyptus trees in Australia and South Africa. Stud Mycol 50:343-358.

Slippers B, Pavlic D, Maleme H, Wingfield MJ (2007) A diverse assemblage of Botryosphaeriaceae infect Eucalyptus in introduced and native environments. In: Proceedings of IUFRO Conference 22-26 October, 2007. Durban, South Africa. 
Smith H, Kemp G, Wingfield M (1994) Canker and die-back of Eucalyptus in South Africa caused by Botryosphaeria dothidea. Plant Pathol 43:1031-1034.

Smith H, Wingfield M, Petrini O (1996) Botryosphaeria dothidea endophytic in Eucalyptus grandis and Eucalyptus nitens in South Africa. For Ecol Manag 89:189-195.

Smith H, Crous P, Wingfield M, Coutinho T, Wingfield B (2001) Botryosphaeria eucalyptorum sp. nov., a new species in the B. dothidea-complex on Eucalyptus in South Africa. Mycologia 93:277285.

Swofford DL (2002) PAUP*: phylogenetic analysis using parsimony (*and other methods). Version 4.0b10a. Sinauer Associates, Sunderland, MA.

Tao G, Liu ZY, Hyde KD, Lui XZ, Yu ZN (2008) Whole rDNA analysis reveals novel and endophytic fungi in Bletilla ochracea (Orchidaceae). Fungal Divers 33:101-122.

Wene E, Schoeneweiss D (1980) Localized freezing predisposition to Botryosphaeria dothidea in differentially frozen woody stems. Can J Bot 58:1455-1458.

White TJ, Bruns S, Lee S, Taylor J (1990) Amplification and direct sequencing of fungal genes for phylogenetics. In: PCR protocols: a guide to methods and applications.Academic, SanDiego, pp $315-322$.

Wingfield M (2003) Increasing threat of disease to exotic plantation forests in the Southern Hemisphere: lessons from Cryphonectria canker. Australas Plant Pathol 32:133-139.

Wingfield M, Rodas C, Myburg H, Venter M, Wright J, Wingfield B (2001) Cryphonectria canker on Tibouchina in Colombia. Forest Pathol 31:297-306.

Yuan Z, Mohammed C (1999) Pathogenicity of fungi associated with stem cankers of Eucalyptus in Tasmania, Australia. Plant Dis 83:1063-1069.

Zhou XD, Xie YJ, Chen SF, Wingfield MJ (2008) Diseases of eucalypt plantations in China: challenges and opportunities. Fungal Divers 32:1-7. 